\title{
PERAN PUSTAKAWAN DALAM PENANAMAN \\ PENDIDIKAN NILAI PADA KEGIATAN USER EDUCATION \\ MAHASISWA BARU STAIN KUDUS TAHUN AKADEMIK 2017/2018 DI UPT PERPUSTAKAAN STAIN KUDUS
}

\author{
Radiya Wira Buwana \\ Institut Agama Islam Negeri Kudus, Jawa Tengah, Indonesia \\ radiyawira2@gmail.com
}

\begin{abstract}
STAIN Kudus librarian's has an important role for the success of user education activity of new students at UPT Library STAIN Kudus. The user education activity in the STAIN Kudus library as a training and education activity for library users, teaches users about how to use services and searches in libraries, as well as teach users how to be polite users, good personalities, obedient to the rules in the library, not plagiarism of scientific work, and mutual respect with the elements of library managers. Education, in this case user education in STAIN Kudus libraries plays a dual role as a form of transfer of knowledge and transfer of value from librarians / managers to library users
\end{abstract}

Keyword: User education, Value education, user

\begin{abstract}
ABSTRAK
Pustakawan STAIN Kudus memiliki peran penting bagi keberhasilan kegiatan user education mahasiswa baru di UPT Perpustakaan STAIN Kudus. Kegiatan user education di
\end{abstract}


perpustakaan STAIN Kudus sebagai sebuah kegiatan pelatihan dan pendidikan bagi pengguna perpustakaan (user/pemustaka) mengajarkan kepada pemustaka tentang bagaimana memanfaatkan layanan dan penelusuran di perpustakaan, juga mengajarkan pemustaka/user untuk bagaimana menjadi pemustaka yang santun, pemustaka yang berkepribadian baik,taat akan tata tertib peraturan di perpustakaan, tidak melakukan plagiasi karya ilmiah, dan saling menghormati dengan unsur pengelola perpustakaan. Pendidikan, dalam hal ini user education di perpustakaan STAIN Kudus berperan ganda sebagai bentuk transfer of knowledge dan transfer of value dari pustakawan/ pengelola perpustakan kepada pemustaka/ user perpustakaan.

Kata Kunci: User education, Pendidikan nilai, pemustaka

\section{A. Pendahuluan}

Perpustakaan di sebuah perguruan tinggi selalu dianggap sebagai sebuah entitas yang sangat penting bagi baik atau buruknya sebuah perguruan tinggi bahkan seiring dengan perkembangan jaman dan teknologi informasi, perpustakaan sering menjadi cermin atau kontrol maju atau mundurnya kualitas perguruan tinggi tersebut. Kegiatan belajar mengajar, pendidikan dan penelitian di sebuah perguruan tinggi tidak akan terlaksana dengan baik tanpa saranan dan prasarana perpustakaan yang memadai Sebagai sebuah unit atau bagian di dalam perguruan tinggi, perpustakaan senantiasa dituntut untuk dapat memberikan pelayanan prima dan pelayanan terbaik bagi seluruh pengguna perpustakaan di lingkungan perguruan tinggi baik itu dosen, mahasiswa, tenaga kependidikan, maupun para stakeholder lain yang membutuhkan layanan dari perpustakaan.

Pada kenyataan di lapangan, user atau pemustaka atau pengguna perpustakaan memiliki kemampuan yang berbeda dalam memanfaatkan layanan di perpustakaan baik itu dalam hal penelusuran koleksi di perpustakaan maupun dalam berperilaku sesuai dengan tata tertib atau aturan yang berlaku di perpustakaan. 
Di sisi lain, kemampuan pengguna perpustakaan dalam memanfaatkan perpustakaan dapat menjadi salah satu faktor kesuksesan proses belajar mengajar, pendidikan dan penelitian di perguruan tinggi.

Berdasarkan pada hal tersebut di atas, untuk mempermudah pengguna perpustakaan dalam mengenal perpustakaan, memanfaatkan jasa layanan perpustakaan, menelusur informasi dari berbagai koleksi di perpustakaan dengan baik dan benar, UPT Perpustakaan STAIN Kudus melaksanakan kegiatan User Education bagi mahasiswa baru STAIN Kudus disetiap awal tahun akademik.

Sebagai sebuah kegiatan pelatihan bagi mahasiswa baru, kegiatan User Education selain ditujukan untuk mengenalkan apa dan bagaimana perpustakaan STAIN Kudus, pada kegiatan ini pustakawan dan pengelola perpustakaan juga menitikberatkan bagaimana adanya proses transfer of value (transfer nilai) atau lebih tepatnya sebuah pendidikan nilai bagi para mahasiswa baru STAIN Kudus. Sebagai sebuah gerbang awal sebelum proses perkuliahan di mulai, diperlukan adanya perubahan mindset/ pola pikir bagi mahasiswa baru dari pola berpikir selama menjadi pelajar SMA/SMK/MA menjadi pola berpikir yang lebih dewasa dan lebih akademis sebagai seorang mahasiswa di perguruan tinggi, pengelola perpustakaan mengharapkan dengan adanya kegiatan User education di UPT perpustakaan dapat menjelaskan dan memberikan gambaran kepada mahasiswa bagaimana menjadi penggunan perpustakaan yang tertib dan taat sesuai aturan di perpustakaan, mengajarkan kepada mahasiswa baru bagaimana untuk berpikir lebih dewasa dan berkarakter dalam interaksi dengan pengelola perpustakaan serta menjadi mahasiswa yang mampu berpikir kritis tetapi juga mampu menghindari plagiasi dalam pembuatan karya ilmiah selama kegiatan perkuliahan di perguruan tinggi. 


\section{B. Pembahasan}

\section{Pengertian Dan Tujuan User Education}

Seiring perkembangan zaman, kebutuhan akan informasi dan literasi ilmiah sudah menjadi kebutuhan wajib bagi civitas akademik di perguruan tinggi. Dianggap sebagai jantungnya perguruan tinggi perpustakaan menjadi sumber akan segala informasi yang dibutuhkan oleh segenap civitas akademika di perguruan tinggi. Seluruh pengguna perpustakan, yang dalam hal ini kita sebut sebagai user, dituntut agar dapat memiliki kemampuan untuk dapat memanfaatkan berbagai macam fasilitas layanan yang ada di perpustakaan secara efektif dan efisien demi keberhasilan studi-nya di perguruan tinggi, misalnya bagaimana menelusur bahan pustaka menggunakan katalog perpustakaan secara offline dan online, atau misalnya menelusur koleksi repository perpustakaan di perguruan tinggi.

Mengingat arti penting perpustakaan bagi penggunanya maka perlu diadakan suatu kegiatan yang memperlihatkan dan menjelaskan manfaat penting perpustakaan bagi seluruh civitas akademikanya. Hal yang sering terjadi adalah bahwa kemampuan pengguna dalam memanfaatkan perpustakaan merupakan dasar yang amat penting dalam mencapai keberhasilan pendidikan. Selain itu perpustakaan diharapkan mampu untuk mendidik penggunanya untuk tertib dan bertanggung jawab dalam memanfaatkan semua koleksinya secara maksimal. Dengan demikian perpustakaan akan berfungsi secara optimal apabila penggunanya dapat mengetahui dengan baik dan cepat dimana dan bagaimana cara menemukan sumber informasi yang mereka butuhkan ${ }^{1}$

Dalam penggunaan dan praktek di perpustakaan, kegiatan user education sering disebut dengan berbagai istilah, seperti pendidikan pengguna, pelatihan pengguna, pelatihan pemakai dan pendidikan pemakai.

1 Rangkuti, Lailan Azizah, "Pentingnya pendidikan pemakai (User education) di perpustakaan perguruan tinggi," Iqra' 8, no. 01 (Mei 2014): 41. 
Ada beberapa hal yang melatarbelakangi perlunya diadakan kegiatan pendidikan pengguna di perpustakaan perguruan tinggi, diantaranya adalah ${ }^{2}$ :

1. Sarana dan prasarana serta koleksi di perpustakaan merupakan suatu investasi yang sangat besar bagi perguruan tinggi, oleh karena itu perpustakaan harus digunakan dan dimanfaatkan semaksimal oleh penggunanya.

2. Pengguna perpustakaan sebagian besar adalah mahasiswa yang ditekankan pada studi mandiri, sehingga diharapkan dengan kegiatan pendidikan pengguna perpustakaan maka mampu untuk lebih memahami dan menggunakan perpustakaan dengan berbagai fasilitas dan layananya secara lebih efektif dan efisien.

3. Dengan adanya kegiatan pendidikan pengguna maka perpustakaan harus mengatur dan membenahi dirinya agar dapat dipergunakan dengan mudah oleh penggunanya.

4. Dengan adanya kegiatan ini maka merupakan suatu kesempatan bagi pustakawan untuk meningkatkan diri bukan hanya sebagai petugas yang hanya melayani pengguna saja tetapiikut serta menyumbangkan pikiran dan keahlianya dalam meningkatkan kualitas layanan perpustakaan.

5. Melalui pendidikan pengguna ini berarti perpustakaan telah dapat dan secara nyata memberikan sesuatu yang amat diperlukan oleh penggunanya.

User education atau yang lebih dikenal dengan pendidikan pengguna merupakan suatu proses dimana pemakai perpustakaan pertama-tama disadarkan oleh luasnya dan jumlah sumber-sumber perpustakaan, jasa layanan, dan penelusuran sumber informasi yang tersedia bagi pemakai dan kedua diajarkan bagaimana menggunakan sumber perpustakaan, jasa layanan, dan sumber informasi tersebut yang tujuanya untuk mengenalkan keberadaan

\footnotetext{
${ }^{2}$ Rangkuti, Lailan Azizah, 41.
} 
perpustakaan, menjelaskan mekanisme penelusuran informasi serta mengajarkan pemakai bagaimana mengeksploitasi sumber daya yang tersedia ${ }^{3}$. Definisi lainya menurut departemen pendidikan dan kebudayaan, direktorat pendidikan Tinggi, pendidikan pemakai merupakan usaha bimbingan atau petunjuk kepada pemakai tentang cara pemanfaatan koleksi bahan pustaka yang disediakan secara efektif dan efisien, selain itu pendidikan pengguna juga didefinisikan sebagai salah satu kegiatan jasa pemanduan dari perpustakaan untuk membantu pemakai perpustakaan dalam meningkatkan ketrampilan pemakai menemukan informasi yang didinginkan secara cepat dan tepat ${ }^{4}$

Dalam melaksanakan kegiatan user education/pendidikan pemakai ada beberapa materi yang dapat disampaikan, Menurut Rice, materi tersebut diklasifikasikan sebagai berikut :

1. Orientasi Pustaka

Dalam tingkatan ini, materi yang disampaikan berupa pengenalan terhadap perpustakaan secara umum, biasanya materi ini diberikan pada saat siswa/mahasiswa baru memasuki suatu lembaga pendidikan yang bersangkutan.

2. Pengajaran Pustaka

Dalam tingkatan ini, materi yang diajarkan berupa penjelasan yang lebih dalam mengenai bahan-bahan perpustakaan secara spesifik.

3. Pengajaran Bibliografi

Dalam tingkatan ini, materi yang diajarkan lebih mengarah sebagai langkah persiapan mengadakan atau sebagai dasar dalam menyusun karya ilmiah ${ }^{5}$

3 Pradhika, Grantino One, "Pengaruh Pendidikan Pengguna (User Education) Terhadap Pemanfaatan Layanan Perpustakaan Di UPT Perpustakaan Universitas Muhammadiyah Suakarta," Libri-Net 3, no. 2 (Juni 2014): 5.

${ }^{4}$ Pradhika, Grantino One, 5.

${ }_{5}$ Pradhika, Grantino One, 6. 
Masih menurut Rice, untuk mengetahui materi dan tujuan apa saja yang ingin dicapai dalam proses pendidikan pemakai, ketiga tingkatan atau jenjang pendidikan pemakai diatas dapat diuraikan sebagai berikut :

1. Orientasi Perpustakaan

- Pengenalan gedung perpustakaan

- Pengenalan katalog dan alat penelusuran lainnya

- Pengenalan beberapa sumber bacaan termasuk bahanbahan rujukan dasar

Tujuan yang ingin dicapai :

- Mengenal fasilitas-fasilitas fisik gedung perpustakaan itu sendiri

- Mengenal bagian-bagian layanan dan staf dari tiap bagian secara tepat

- Mengenal layanan-layanan khusus seperti penelusuran melalui komputer, layanan peminjaman, dll

- Mengenal kebijakan- kebijakan perpustakaan seperti prosedur menjadi anggota, jam-jam layanan perpustakaan, dll

- Mengenal pengorganisasian koleksi dengan tujuan untuk mengurangi kebingungan pemakai dalam mencari bahan-bahan yang dibutuhkan.

- Termotivasi untuk datang kembali dan menggunakan sumber-sumber yang ada di perpustakaan.

2. Pengajaran Perpustakaan

Materi yang diajarkan merupakan penjelasan lebih dalam lagi mengenai bahan-bahan perpustakaan secara spesifik, materinya antara lain :

- Teknik penggunaan indeks, katalog, bahan-bahan rujukan, dan alat bibliografi

- Penggunaan bahan atau sumber pustaka sesuai dengan 
subyek atau jurusan.

- Melaksanakan teknik-teknik penelusuran informasi dalam sebuah tugas penelitian atau pembuatan karya ilmiah lainya.

Tujuan yang ingin dicapai :

- Dapat menggunakan pedoman pembaca untuk mencari bahan -bahan artikel

- Dapat menemukan buku-buku yang berhubungan dengan subyek khusus melalui katalog.

- Dapat menggunakan bentuk mikro dan alat-alat baca lainya secara tepat.

- Dapat menggunakan alat rujukan khusus seperti ensiklopedi, alamanak, bibliografi,dll

- Menemukan koleksi visual dan dapat menggunakanya.

- Mengetahui sumber-sumber yang tersedia di perpustakaan lain dan dapat melakukan permintaan peminjaman

- Melakukan suatu penelusuran dalam layanan pengindeksan seperti pada pusat informasi sumber pendidikan dan dapat menemukan dan menggunakan hasil-hasil sitasi.

3. Pengajaran Bibliografi.

Materi yang diajarkan lebih condong sebagai langkah persiapan mengadakan atau sebagai dasar penelitian dalam rangka menyusun karya akhir. Pada level ketiga ini bisa ditawarkan melalui mata ajar formal sebagai bagian dari kurikulum muatan lokal (mulok), materi yang ingin dicapai antara lain :

- Informasi dan pengorganisasianya

- Tajuk subyek, "Vocabulary Control" dalam penelitian, dan definisi suatu topik karya ilmiah

- Macam-macam sumber untuk penelitian. 
- Membuat kerangka teknik dan perencanaan suatu karya ilmiah

- Teknik-teknik membuat catatan dalam karya ilmiah.

- Gaya, catatan kaki, rujukan dan sumber bahan bacaan.

- Strategi penelitian, kesempurnaan dalam penelitian, dan pemakainan yang tepat layanan koleksi yang diberikan perpustakaan.

- Membuat/Menulis karya ilmiah ${ }^{6}$.

Dalam pendidikan pengguna, Malley membedakan pendidikan pengguna kedalam dua hal yaitu library orientation dan library instruction. Orientasi perpustakaan bertujuan untuk mengenalkan pengguna akan keberadaan perpustakaan dan layanan apa saja yang tersedia di perpustakaan juga memungkinkan pengguna mempelajari secara umum bagaimana menggunakan perpustakaan, jam buka, letak koleksi tertentu dan cara meminjam koleksi perpustakaan. Intruksi perpustakaan bertujuan agar para pemakai dapat memperoleh informasi yang diperlukan dengan tujuan tertentu dengan menggunakan semua sumber daya dan bahan yang tersedia di perpustakaan.Intruksi perpustakaan berkaitan dengan temu kembali informasi ${ }^{7}$.

Tujuan utama diadakanya kegiatan pendidikan pengguna perpustakaan adalah untuk memperkenalkan ke pemakai bahwa perpustakaan adalah suatu sistem yang didalamnya terdapat koleksi dan sumber informasi lain ${ }^{8}$. Menurut Rahayuningsih, ada bermacam-macam tujuan yang hendak dicapai diantaranya adalah:

1. Agar pemakai menggunakan perpustakaan secara efektif dan efisien

${ }^{6}$ Abdul Hak,Ade, "Pendidikan pemakai: Perubahan perilaku pada siswa madrasah dalam sistem pembelajaran berbasis perpustakaan," AL-MAKTABAH 6, no. 1 (Oktober 2004): 42.

7 Rangkuti, Lailan Azizah, "Pentingnya pendidikan pemakai (User education) di perpustakaan perguruan tinggi," 42 .

${ }^{8}$ Rangkuti, Lailan Azizah, 42. 
2. Agar pemakai dapat menggunakan sumber-sumber literatur dan dapat menemukan informasi yang relevan dengan masalah yang dihadapi.

3. Memberi pengertian kepada mahasiswa akan tersedianya informasi di perpustakaan dalam bentuk tercetak atau tidak.

4. Memperkenalkan kepada mahasiswa jenis-jenis koleksi dan ciri-cirinya.

5. Memberikan latihan atau petunjuk dalam menggunakan perpustakaan dan sumber-sumber informasi agar pemakai mampu meneliti suatu masalah, menemukan materi yang relevan, mempelajari dan memecahkan masalah.

6. Mengembangkan minat baca pemakainya

7. Memperpendek jarak antara pustakawan dengan penggunanya ${ }^{9}$

\section{Pengertian Dan Peran Pustakawan}

Dalam sebuah institusi perpustakaan, pustakawan menjadi ujung tombak bagi kualitas perpustakaan itu sendiri. Dianalogikan jika perpustakaan adalah sebuah Personal Computer (PC) maka pustakawan adalah perangkat RAM (random access memory) di dalam PC tersebut. Kualitas pustakawan berbanding lurus dengan kualitas perpustakaan, bahkan kualitas pustakawan sering menjadi cerminan baik atau tidaknya kualitas perpustakaan.Semakin baik kualitas pustakawan, semakin cerdas kualitas pustakawan dan semakin "melek teknologi" pustakawan maka semakin berkualitas perpustakaanya.

Di dalam KBBI (kamus besar bahasa indonesia), pustakawan diartikan sebagai orang yang bergerak dalam bidang perpustakaan, ahli perpustakaan ${ }^{10}$. Ikatan Pustakawan Indonesia (IPI) sebagai organisasi yang menghimpun para pustakawan dalam kode etiknya

${ }^{9}$ Rangkuti, Lailan Azizah, 42-43.

10 "Kamus Besar Bahasa Indonesia Versi Daring," diakses 15 Mei 2018, www.kbbi.web.id. 
menyatakan bahwa pustakawan adalah seorang yang melaksanakan kegiatan perpustakaan dengan jalan memberikan pelayanan kepada masyarakat sesuai dengan tugas lembaga induknya berdasarkan ilmu pengetahuan, dokumentasi, dan informasi yang dimilikinya melalui pendidikan. Pustakawan adalah seseorang yang berkarya secara profesional di bidang perpustakaan dan informasi ${ }^{11}$

Dalam pandangan masyarakat secara umum, profesi pustakawan masih sering dianggap sebagai sebuah profesi yang hanya menjaga dan menunggui perpustakaan, kurang lebihnya hanya menjalani sebuah kegiatan meminjamkan dan mengembalikan buku bagi pengguna perpustakaan. Sudah menjadi rahasia umum, stereotif yang sering masyarakat awam sematkan tentang profil seorang pustakawan adalah sosok yang sudah berusia lanjut, berkacamata, kutu buku, tidak ramah dan sebagai sebuah profesi yang sangat membosankan.

Menurut Pasal 1 ayat (8) Undang-undang Nomor 43 Tahun 2007 tentang perpustakaan, tugas dan tanggung jawab seorang pustakawan adalah melaksanakan pengelolaan dan pelayanan perpustakaan. Kata "pengelolaan dan pelayanan perpustakaan" ini berdampak dan berimplikasi luas. Pengelolaan dan pelayanan perpustakaan seharusnya tidak berhenti pada melayani para users dalam meminjam buku. Pengelolaan dan pelayanan perpustakaan harus mengarah pada pengembangan budaya literasi dan pengembangan ilmu pengetahuan ${ }^{12}$.

Pada perpustakaan perguruan tinggi, pustakawan dituntut untuk lebih "fleksibel,kreatif, open minded, dan cerdas" bagi pengguna atau user dari perpustakaan civitas akademika yang terdiri dosen dan mahasiswa yang membutuhkan pelayanan lebih, dalam menelusur sumber informasi yang dibutuhkan mereka untuk kebutuhan penelitian dan pembuatan karya ilmiah selama proses belajar mengajar di perguruan tinggi maupun sebagai

11 Hermawan, Rahman dan Zen,Zulfikar, Etika kepustakawanan (Yogyakarta: CV Sagung Seto, 2010), 46.

${ }^{12}$ Hidayat, Aat, "REKONSTRUKSI PERAN PUSTAKAWAN DI ERA GLOBALISASI," LIBRARIA: Jurnal Perpustakaan 4, no. 2 (2017): 470. 
pengelola informasi yang dapat menjadi mitra diskusi berimbang bagi segenap civitas akademika di perpustakaan perguruan tinggi.

Secara ringkas sebagaimana dijabarkan oleh A.C. Sungkanan Hadi, peran pustakawan sebagai pengelola sumber informasi adalah :

a. Menyediakan dan mengembangkan koleksi sumber informasi yang relevan dengan kebutuhan pengguna, mutakhir, dan komprehensif. Oleh karena itu, pustakawan perlu memiliki kesiagaan informasi (information awareness), yakni kemauan untuk selalu berusaha memperoleh informasi yang mutakhir dan komprehensif, selalu mengikuti perkembangan penerbitan, termasuk untuk peningkatan pengetahuan dan kualitas diri sendiri,

b. Melakukan pengorganisasian koleksi sumber informasiberdasarkan sistem yang andal dan terpercaya, termasuk sistem yang berbasis teknologi informasi, agar setiap carik informasi di dalam koleksi tersebut dapat diketahui keberadaanya, dan dapat diketemukan dengan mudah, cepat dan tepat.

c. Melakukan pemanduan bagi pengguna dalam menelusur dan/atau menjelajahi samudra informasi yang semakin luas, sehingga pengguna dapat memperoleh informasi yang sesuai dengan kebutuhanya (the right information for the right user).

d. Melkukan upaya-upaya promosi dan pembinaan minat baca masyarakat, agar melalui pemanfaatan intensif koleksi sumber informasi yang ada dapat dibangun dan dikembangkan suatu masyarakat yang gemar membaca dan gemar belajar (reading and learning society).

e. Melakukan upaya-upaya perekaman informasi dan pengetahuan lokal, termasuk upaya digitalisasi informasi, agar dapat diakses secara luas oleh masyarakat 
pengguna tanpa batas ruang dan waktu. Oleh karena itu, pustakawan perlu siaga untuk berkembang menjadi pengelola ilmu pengetahuan (knowledge manager), bukan hanya pengelola buku, bukan pula hanya pengelola informasi ${ }^{13}$.

Sebagai pustakawan pada lembaga pendidikan, di perguruan tinggi pustakawan dapat berperan pula sebagai dosen atau peneliti, minimal sebagai mitra peneliti, dalam banyak hal pustakawan memainkan berbagai peran (berperan ganda) yang dapat disingkat dengan akronim EMAS dengan rincian sebagai berikut ${ }^{14}$ :

a. Edukator

Sebagai edukator (pendidik), pustakawan dalam melaksanakan tugasnya harus berfungsi dan berjiwa sebagai pendidik. Sebagai pendidik, ia harus melaksanakan fungsi pendidikan yaitu mendidik, mengajar dan melatih. Mendidik adalah mengembangkan kepribadian, mengajar adalah mengembangkan kemampuan berfikir, dan melatih adalah membina dan mengembangkan keterampilan.

b. Manajer

Pada hakikatnya pustakawan adalah "manajer informasi" yang mengelola informasi pada satu sisi, dengan pengguna informasi pada sisi lain. Informasi yang banyak dan terdapat dalam berbagai wadahyang jumlah selalu bertambah harus dikelola dengan baik. Kebutuhan informasi pengguna merupakan dasar pengelolaan informasi. Bila dikaitkan dengan lembaga jasa lainya, maka pustakawan meiliki kedudukan yang sama dengan manajer sebuah toko buku, restoran, hotel, dan sebagainya.

\footnotetext{
${ }^{13}$ Hidayat, Aat, 472-73.

${ }^{14}$ Hermawan, Rahman dan Zen,Zulfikar, Etika kepustakawanan, 57.
} 


\section{c. Administrator}

Sebagai administrator, pustakawan harus mampu menyusun, melaksanakan, dan mengevaluasi program perpustakaan, serta dapat melakukan analisis atas hasil yang telah dicapai, kemudian melakukan upaya-upaya perbaikan untuk mencapai hasil yang lebih baik.

d. Supervisor

Sebagai supervisor, pustakawan harus :

1. Dapat melaksanakan pembinaan profesional, untuk mengembangkan jiwa kesatuan dan persatuan antar sesama pustakawan, sehingga dapat menumbuhkandan peningkatan semangat kerja dan kebersamaan.

2. Dapat meningkatkan prestasi, pengetahuan dn keterampilan, baik rekan-rekan sejawat maupun masyarakat pengguna yang dilayaninya.

3. Mempunyai wawasan yang luas, pandangan jauh kedepan, memahami beban kerja, hambatanhambatan, serta bersikap sabar, tetapi tegas, adil obyektif dalam melaksanakan tugasnya.

4. Mampu berkoordinasi, baik dengan sesama pustakawan maupun dengan para pembinanya dalam menyelesaikan berbagai persoalan dan kendala, sehingga mampu meningkatkan kinerja unit organisasinya.

\section{Pendidikan Nilai}

\section{a. Pengertian Nilai}

Dalam Kamus Besar Bahasa Indonesia, nilai memiliki banyak pengertian, antara lain : 1) harga ,2) harga uang, 3) angka kepandaian, biji, ponten, 4) banyak sedikitnya isi, kadar, mutu, 5) sifat-sifat (hal-hal) yang penting atau berguna bagi kemanusiaan, 6) 
sesuatu yang menyempurnakan manusia sesuai dengan hakikatnya ${ }^{15}$. Sebagai soerang ahli psikologi kepribadian, Gordon Alport mendefinisikan nilai sebagai keyakinan yang membuat seseorang bertindak atas dasar pilihanya ${ }^{16}$. Bagi Allport, nilai terjadi pada wilayah psikologis yang disebut keyakinan. Seperti ahli psikologi pada umumnya, keyakinan ditempatkan sebagai wilayah psikologi yang lebih tinggi dari wilayah lainya seperti hasrat, motif, sikap, keinginan, dan kebutuha. Karena itu, keputusan benar-salah, baikburuk, indah-tidak indah pada wilayah ini merupakan hasil dari serentetan proses psikologis yang kemudian mengarahkan individu pada tindakan dan perbuatan yang sesuai dengan nilai pilihannya ${ }^{17}$. Kupperman mendefinisikan nilai sebagai patokan normatif yang mempengaruhi manusia dalam menentukan pilihanya di antara cara-cara tindakan alternatif, definisi ini memiliki tekanan utama pada norma sebagai faktor eksternal yang mempengaruhi perilaku manusia $^{18}$. Sidi Gazalba mengartikan nilai adalah sesuatu yang bersifat abstrak, dan ideal. Nilai bukan benda kongkret, bukan fakta, tidak hanya sekadar soal penghayatan yang dikehendaki dan tidak dikehendaki, yang disenangi dan tidak disenangi ${ }^{19}$. Menurut Fraenkel, nilai adalah standar tingkah laku, keindahan, keadilan, kebenaran dan efisiensi yang mengikat manusia dan sepatutnya dijalankan dan dipertahankan ${ }^{20}$. Untuk pengertian nilai yang lebih sederhana, nilai adalah rujukan dan keyakinan dalam menentukan pilihan ${ }^{21}$. Berdasarkan beberapa pengertian di atas, bisa digarisbawahi bahwa nilai merupakan esensi yang melekat pada sesuatu yang sangat berarti bagi kehidupan manusia ${ }^{22}$

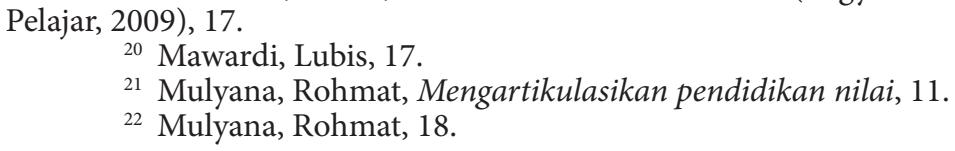


Nilai yang dimiliki seseorang dapat membentuk sikap dan ekspresi suka atau tidak suka, sehingga dapat dikatakan nilai adalah sebuah faktor yang mempengaruhi pembentukan sikap. Deangan mempelajari nilai, seseorang akan mengetahui yang harus diperbuatnya. Dengan demikian, nilai memiliki dasar pembenaran atau sumber pandangan dari berbagai hal, seperti metafisika, teologi, etika, estetika, dan logika ${ }^{23}$

\section{b. Pengertian dan Tujuan Pendidikan Nilai}

Pendidikan merupakan sebuah hal penting dalam kehidupan manusia. Pendidikan bagi kehidupan manusia merupakan kebutuhan primer atau mutlak yang harus dipenuhi sepanjang hayat, tanpa pendidikan mustahil suatu nkelompok manusia dapat hidup berkelanjutan dengan cita-cita untuk maju, sejahtera dan bahagia menurut konsep pandangan hidup. Dalam pengertian sederhana dan umum, makna pendidikan adalah usaha sadar manusia untuk menumbuhkan dan mengembangkan potensi-potensi pembawaan baik jasmani maupun rohani sesuai dengan nilai-nilai yang ada di dalam masyarakat dan agama ${ }^{24}$.

Pendidikan bertujuan tidak sekedar proses alih budaya dan alih ilmu pengetahuan (transfer of knowledge) tetapi juga sekaligus sebagai proses alih nilai (transfer of value) artinya pendidikan disamping proses peralihan dan tarnsmisi pengetahuan juga berkenaan dengan proses perkembangan dan pembentukan kepribadian atau karakter masyarakat dalam rangka internalisasi nilai-nilai budi pekerti kepada peserta didik ${ }^{25}$. Kaitan antara nilai dengan pendidikan memang sangat erat, pendidikan memiliki peran utama yang diperlukan untuk menyampaikan nilai-nilai agar dapat dimiliki oleh peserta didik misalkan nilai kebenaran, keindahan, kesopanan, kejujuran, kebaikan dan nilai tanggung jawab.

${ }^{23}$ Qiqi Yulianti Zakiah dan Rusdiana, Pendidikan Nilai: Kajian Teori dan Praktik di Sekolah (Bandung: Pustaka Setia, 2014), 64.

${ }^{24}$ Yuniarti, Yuyun, "Pendidikan Ke Arah Pembentukan Karakter," Tarbawiyah 11, no. 2 (Desember 2014): 263.

${ }^{25}$ Yuniarti, Yuyun, 263. 
Sastrapratedja mengemukakan bahwa pendidikan nilai adalah penanaman dan pengembangan nilai-nilai pada diri seseorang ${ }^{26}$ Dalam pengertian yang hampir sama, Mardiatmadja mendefinisikan pendidikan nilai sebagai bantuan terhadap peserta didik agar menyadari dan mengalami nilai-nilai serta menempatkanya secara integral dalam keseluruhan hidupnya ${ }^{27}$. Dalam Pengertian yang lebih operasional, David Aspin membuat definis pendidikan nilai sebagai bantuan untuk mengembangkan dan mengartikulasikan kemampuan pertimbangan nilai atau keputusan moral yang dapat melembagakan kerangka tindakan manusia $^{28}$. Dari definisi-definisi tersebut dapat ditarik suatu definisi pendidikan nilai yang mencakup keseluruhan aspek sebagai pengajaran atau bimbingan kepada peserta didik agar menyadari nilai kebenaran, kebaikan, dan keindahan, melalui proses pertimbangan nilai yang tepat dan pembiasaan bertindak yang konsisten ${ }^{29}$.

Secara umum, Pendidikan nilai dimaksudkan untuk membantu peserta didik agar memahami, menyadari dan mengalami nilai-nilai serta mampu menempatkanya secara integral dalam kehidupan ${ }^{30}$. Dalam proses pendidikan nilai tindakan-tindakan pendidikan yang lebih spesifik, dimaksud untuk mencapai tujuan yang lebih khusus. Seperti dikemukakan oleh komite Asia and The Pasific Programme of Education Innovation for Development (APEID), pendidikan nilai secara khusus ditujukan untuk:

1. Menerapkan pembentukan nilai kepada anak.

2. Menghasilkan sikap yang mencerminkan nilai-nilai yang diinginkan dan

${ }^{26}$ Mulyana, Rohmat, Mengartikulasikan pendidikan nilai, 119.

${ }^{27}$ Mulyana, Rohmat, 119.

${ }^{28}$ Mulyana, Rohmat, 119.

${ }^{29}$ Mulyana, Rohmat, 119.

${ }^{30}$ Mulyana, Rohmat, 119. 
3. Membimbing perilaku yang konsisten dengan nilai-nilai tersebut ${ }^{31}$.

Dengan demikian, tujuan pendidikan nilai meliputi tindakan mendidik yang berlangsung mulai dari usaha penyadaran nilai hingga perwujudan perilaku yang bernilai ${ }^{32}$. Sasaran pendidikan nilai adalah penanaman nilai-nilai luhur kepada peserta didik. Untuk mencapai tujuan dan sasaran secara efektif, berbagai pendekatan, model dan metode dapat digunakan dalam proses pendidikan nilai. Hal ini penting untuk memberikan variasi pada proses pendidikan sehingga menarik dan tidak membosankan peserta didik ${ }^{33}$

\section{Kegiatan User Education Tahun Akademik 2017/2018 Di Upt Perpustakaan Stain Kudus}

\section{a. Dasar Hukum Kegiatan}

Kegiatan user education di UPT Perpustakaan STAIN Kudus hanya diperuntukan bagi mahasiswa baru STAIN Kudus tahun akademik 2017/2018. Semua mahasiswa baru, wajib mengikuti kegiatan user education yang diadakan oleh UPT perpustakaan STAIN Kudus ini sebagai syarat wajib untuk menjadi anggota aktif perpustakaan. Kegiatan ini memiliki dasar hukum pelaksanaan yaitu SK Ketua STAIN Kudus Nomor. 15446/ Sti.05/OT.01.3/09/2017 tertanggal 4 September 2017 tentang pengangkatan tim pelaksanadan pemandu User education calon anggota baru perpustakaan Sekolah Tinggi Agama Islam Negeri Kudus Tahun 2017.

\section{b. Pelaksanaan Kegiatan}

Kegiatan user education UPT Perpustakaan STAIN Kudus tahun akademik 2017/2018 ini dilaksanakan mulai hari senin tanggal 15 September 2017 dan selesai pada hari Jumat tanggal

${ }^{31}$ Qiqi Yulianti Zakiah dan Rusdiana, Pendidikan Nilai: Kajian Teori dan Praktik di Sekolah, 64.

${ }^{32}$ Qiqi Yulianti Zakiah dan Rusdiana, 64.

${ }^{33}$ Qiqi Yulianti Zakiah dan Rusdiana, 64. 
15 September 2017. Lokasi kegiatan dibagi di dua tempat yaitu di gedung perpustakaan STAIN Kudus dan gedung PKM Mahasiswa. Peserta dari kegiatan ini adalah semua mahasiswa baru STAIN Kudus angkatan 2017/2018 yang berjumlah 2611 mahasiswa dari seluruh jurusan dan mahasiswa angkatan lama yang belum mengikuti user education berjumlah 6 mahasiswa.

Kegiatan user education dipandu oleh 6 pemateri dari UPT Perpustakaan STAIN Kudus yaitu Anisa Listiana, M.Ag selaku kepala perpustakaan STAIN Kudus, Shofaussamawati, M.S.I selaku Sekretaris perpustakaan STAIN Kudus, 3 pustakawan perpustakaan STAIN Kudus yaitu Yuyun Widayanti, A.Md, Dewi Yantiningsih, A.Md, dan Isti Mawwadah,A.Md, serta Radiya Wira Buwana, S.Pd.I selaku pengadministrasi perpustakaan STAIN Kudus.

Kegiatan user education ini secara teknis dilaksanakan dimana setiap pemateri memandu satu kelompok mahasiswa yang berjumlah 100 sampai 115 mahasiswa dalam durasi waktu kurang lebih 1,5 jam atau 90 menit. User education dilakukan di dua lokasi, yaitu materi teori dasar di gedung PKM mahasiswa kemudian materi praktek lapangan langsung di lokasi perpustakaaan STAIN Kudus.

Diawali dengan mahasiswa melakukan regristrasi absen dan pengambilan materi teori di gedung PKM terlebih dulu, selanjutnya mahasiswa memasuki gedung PKM untuk mengikuti paparan materi oleh pemateri melalui slide presentasi powerpoint yang memberikan penjelasan berkaitan dengan tata tertib perpustakaan, sistem pelayanan perpustakaan, sistem keanggotaan, rincian koleksi pustaka yang ada di perpustakaan hingga penelusuran koleksi pada program aplikasi LYBSYS yang dimiliki oleh UPT Perpustakaan STAIN Kudus. Kegiatan penyampaian teori awal atau teori dasar di gedung PKM mahasiswa dengan durasi waktu berkisar 30 menit biasanya diakhiri dengan sesi tanya jawab oleh mahasiswa baru sebagai peserta kepada pemateri ataupun sebaliknya sesi tanya jawab dilakukan oleh pemateri kepada peserta sebagai bentuk tolak 
ukur apakah mereka sudah memahami apa materi yang sudah disampaikan oleh pemateri.

Secara teoritis, ada beberapa teknik atau metode yang dapat digunakan dalam kegiatan user education, antara lain : presentasi/kuliah di kelas, wisata perpustakaan, penggunaan audio visual, permainan dan tugas mandiri, penggunaan buku pedoman atau pamflet ${ }^{34}$

- Presentasi atau ceramah di kelas

Penjelasan mengenai pengenalan dan pelayanan perpustakaan dapat diberikan di kelas dengancara memberikan ceramah secara umum atau melalui demonstrasi. Idealnya jumlah peserta perkelas kurang lebihg antara 15-30 orang. Untuk mencapai hasil yang optimal dalam metode ini para peserta diberikan beberapa tugas terstruktur dan latihan yang memungkinkan mereka mampu menggunakan perpustakaan secara mandiri. Pelaksanaan metode ini selyaknya dapat dilakukan dengan metode wisata perpustakaan, agar peserta lebih memahami dan akrab dengan dunia perpustakaan yang sebenarnya.

- Wisata Perpustakaan

Beberapa teknik yang bisa dilakukan dalam memandu wisata perpustakaan, antara lain :

1. Menciptakan suasana yang bersahabat dan informal serta terbuka untuk beberapa pertanyaan.

2. Usahakan berbicara tidak terlalu cepat dan sensitif terhadap kebingunan yang dialami pemakai

3. Gunakan sarana pembantu untuk memperjelas sesuatu yang didiskusikan, misal: penggunaan katalog.

4. Buatlah para peserta berperan aktif untuk mencoba mencoba menggunakan fasilitas yang ada.

${ }^{34}$ Abdul Hak,Ade, "Pendidikan pemakai: Perubahan perilaku pada siswa madrasah dalam sistem pembelajaran berbasis perpustakaan," $120-22$. 
5. Waktu yang digunakan tidak terlalu lama, maksimal 45 menit.

6. Sediakan buku panduan yang dapat membantu mereka selama mengikuti wisata perpustakaan tersebut.

- Penggunaan Audio Visual

Teknik ini biasanya dilakukan untuk wisata mandiri per individual (perorangan), di antaranya adalah penggunaan kaset, televisi, slide,dll.

- Permainan dan Tugas Mandiri

Metode ini merupakan salah satu cara yang cukup efektif dalam mengajarkan bagaimana cara menemukan informasi yang dibutuhkan. Biasanya lebih sesuai diterapkan untuk pemakai perpustakaan usia anak sekolah dasar dan menengah. Prmainan sangat berguna dalam meningkatkan kemampuan anak sehingga mereka lebih dapat menikmati penggunaan perpustakaan. Biasanya, metode ini dilakukan di tingkat lebih tinggi untuk menghilangkan kejenuhan yang mungkin ada ketika proses pembelajaran dengan metode lain berlangsung.

- Penggunaan Buku Pedoman atau Pamflet

Teknik ini biasanya menuntut pemakai untuk mempelajari sendiri mengenal perpustakaan melalui berbagai keterangan yang ada pada buku panduan atau pamflet, dan biasanya diterapkan ketika peserta melaksanakan wisata pendidikan.

Untuk bagian ke-2, mahasiswa langsung memasuki lokasi perpustakaan STAIN Kudus, atau dalam hal ini peserta atau mahasiswa baru melaksanakan wisata perpustakaan, dimana pada bagian ini pemateri akan menyampaikan gambaran secara langsung bagaimana bagian-bagian, wewenang, tugas pokok dan fungsinya yang ada di dalam perpustakaan STAIN Kudus selama kurang lebih 1 jam atau 60 menit, baik itu bagian absensi loker, bagian administrasi, bagian koleksi referensi, bagian koleksi 
sirkulasi, maupun bagian koleksi tandon. Pada sesi ini peserta (mahasiswa baru) akan mempraktekan langsung mulai dari praktek meminjam kunci loker, praktek langsung bagaimana meminjam, mengembalikan, maupun memperpanjang masa pinjam koleksi pustaka di perpustakaan.Tidak lupa, di akhir sesi ini akan dilakukan sesi tanya jawab dan sesi evaluasi bagi peserta user education seperti pada sesi pertama saat penyampaian materi dasar di gedung PKM. Selain hal teknis dan administratif tersebut, peserta dalam kegiatan user education juga diarahkan untuk mengenal dan berinteraksi dengan para pengelola perpustakaan (staf perpustakaan), karena dalam proses perkuliahan para pengelola perpustakaan secara langsung akan menjadi mitra bagi mahasiswa tersebut dalam meanfaatkan layanan di UPT perpustakaan STAIN Kudus.

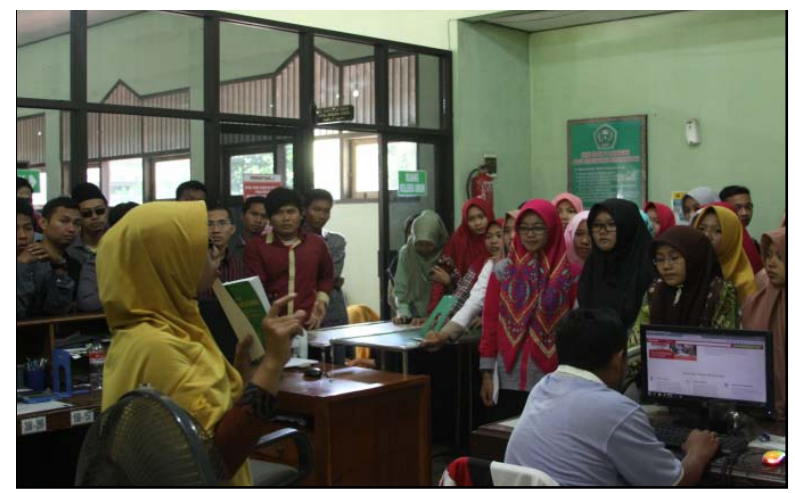

Gambar 1: Pustakawan STAIN Kudus sedang memberikan materi cara meminjam dan mengembalikan koleksi perpustakaan

\section{c. Peran Pustakawan dalam Penanaman Pendidikan Nilai}

Telah disebutkan dalam pembahasan di atas, bahwa salah satu fungsi pustakawan adalah sebagai sosok edukator/pendidik. Sebagai seorang pustakawan pendidik, pustakawan juga harus memahami prinsip-prinsip yang dikembangkan oleh Ki Hajar Dewantara, yaitu : "ing ngarso sung tuloda, ing madya mangun karsa, tut wuri handayani”.

- "ing ngarso sung tulada", artinya ia harus mampu lewat sikap dan perbuatanya menjadikan dirinya sebagai pola 
anutan dan ikutan orang-orang yang dilayaninya.

- "ing madyo mangun karso" berarti ia harus membangkitkan semangat ber-swakarsa dan berkreasi pada orang-orang yang dilayaninya.

- "tut wuri handayani", ia harus mampu mendorong orang-orang yang dilayaninya agar berani berjalan di depan dan sanggup bertanggung jawab ${ }^{35}$.

Perbedaan yang mencolok dengan guru atau pendidik lain adalah dalam sistem pemberian pelajaran atau informasi. Pustakawan umumnya menyediakan informasi melalui kegiatan penyediaan berbagai sumber informasi, sedikit bicara tetapi banyak informasi, sedangkan edukator banyak memberikan pelajaran atau informasi melalui lisan dan bersifat langsung ${ }^{36}$.Bercermin dari semangat ajaran Ki hajar dewantara, dalam kegiatan user education di UPT perpustakaan STAIN Kudus, pustakawan di perpustakaan STAIN Kudus harus senantiasa mampu menyelipkan pendidikan nilai dalam kegiatan user education.

Kemajuan zaman dan teknologi jika tidak disikapi dengan bijaksana oleh generasi masa kini, atau yang sering disebut dengan generasi milenial sering menyebabkan menurunya perilaku moral, akhlak pribadi dan sopan santun generasi masa kini. Sebagai sosok yang sedang mencari jatidiri-nya sebagai peralihan dari pola pikir remaja SMA menjadi seorang mahasiswa, terkadang sikap besar kepala, sok pintar ataupun "semau gue" seringkali diaplikasikan tidak pada tempatnya, bisa juga sikap tersebut juga diterapkan saat mahasiswa baru tersebut berada di dalam perpustakaan.

Melanggar tata tertib perpustakaan misalnya, selalu menjadi wujud pertama "kenakalan" mahasiswa baru tersebut di dalam perpustakaan, masuk ke perpustakaan memakai jaket, memakai topi, ataupun membawa tas. Lebih berat lagi, karena faktor kebutuhan akan koleksi pustaka yang banyak, mahasiswa biasanya

${ }^{35}$ Qiqi Yulianti Zakiah dan Rusdiana, Pendidikan Nilai: Kajian Teori dan Praktik di Sekolah, 58.

${ }^{36}$ Qiqi Yulianti Zakiah dan Rusdiana, 58. 
merusak buku koleksi dengancara merobek halaman yang mereka butuhkan, atau bahkan entah bagaimana caranya mereka berencana untuk mencuri koleksi buku yang ada di perpustakaan. Dari sisi akademis, kemajuan teknologi juga semakin mempermudah mahasiswa untuk melakukan copy paste referensi-referensi ilmiah yang mereka butuhkan untuk membuat tugas yang diberikan oleh dosen, hal ini tentunya sebuah hal yang sangat tidak diperbolehkan dalam etika akademis.

Melihat kenyataan-kenyataan dia atas, sudah menjadi kewajiban bagi pustakawan di perpustakan STAIN Kudus melalui kegiatan user education untuk menyiapkan generasi-generasi mahasiswa baru STAIN Kudus yang lebih sopan dan berkarakter santun serta yang paling penting adalah rasa sosial untuk merasa memiliki perpustakaan STAIN Kudus sebagai bagian yang tidak bisa mereka pisahkan selama proses perkuliahan di STAIN Kudus.

Bloom menyatakan bahwa pemanfaatan layanan perpustakaan sebaiknya mencakup beberapa kawasan perilaku, antara lain :

1. Pengetahuan (kognitif)

Merupakan kemampuan pengguna untuk mengetahui cara pemanfaatan layanan perpustakaan, memahami status keanggotaan perpustakaan mereka, memahami dan menaanti peraturan yang diterapkan di perpustakaan, dan yang utama memahami fasilitas layanan yang disediakan oleh perpustakaan.

2. Sikap (afektif)

Merupakan kemampuan pengguna dalam mengartikan perpustakaan sebagai sarana untuk mencari informasi dan belajar, sehingga perpustakaan akan selalu menjadi tempat utama dalam meningkatkan khasanh ilmu pengguna.

3. Ketrampilan (psikomotorik) 
Merupakan kemampuan pengguna untuk menggunakan layanan perpustakaan semaksimal mungkin, merawat dan menjaga koleksinya ${ }^{37}$

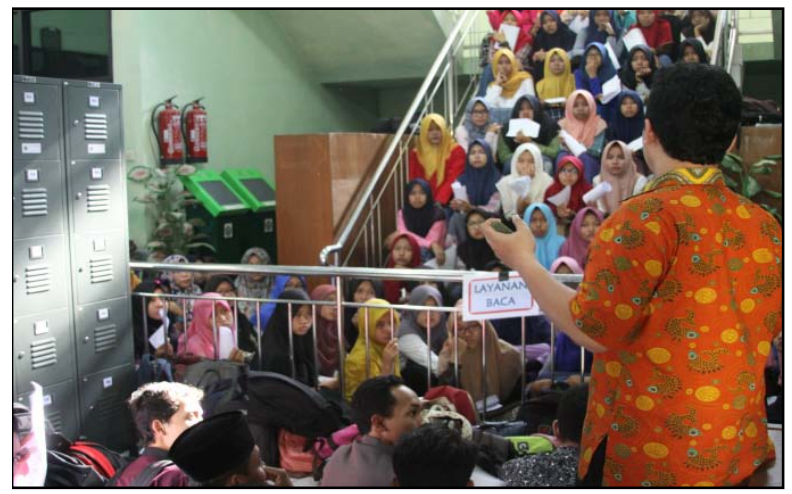

Gambar 2: Pustakawan STAIN Kudus sedang memberikan materi tata tertib di UPT perpustakaan STAIN Kudus dalam kegiatan User Education

Bentuk nilai-nilai yang dapat ditanamkan oleh pustakawan kepada pemustaka dalam kegiatan user education dapat disebutkan seperti berikut :

1. Nilai Kesantunan dan Kesopanan

Melalui kegiatan user education diharapkan pustakawan dapat menanamkan kepada pemustaka untuk menjadi pemustaka yang santun kepada sesama pemustaka lain, bersikap santun dengan pengelola perpustakaan, bersikap santun dengan dosen selama proses perkuliahan.

2. Nilai Kejujuran

Kejujuran merupakan sebuah hal yang sangat penting, kualitas manusia bisa dilihat dari kejujuranya. Dalam kegiatan user education, pustakawan harus bisa memberikan teladan terhadap pemustaka tentang bagaimana pentingnya nilai kejujuran, seperti tidak melakukan plagiasi karya ilmiah, tidak mengambil atau mencuri buku koleksi

37 Pradhika, Grantino One, "Pengaruh Pendidikan Pengguna (User Education) Terhadap Pemanfaatan Layanan Perpustakaan Di UPT Perpustakaan Universitas Muhammadiyah Suakarta," 6. 
perpustakaan bahkan terkadang pada beberapa kasus di perpustakaan STAIN Kudus ada beberapa oknum pemustaka yang berani melakukan pencurian terhadap barang-barang milik pemustaka lainnya.

3. Nilai Kerapian, Kebersihan dan Keindahan

Pemustaka diharapkan melalui kegiatan user education dapat menjadi pemustaka yang bisa menjaga kerapian koleksi perpustakaan dengan tidak melakukan coratcoret pada koleksi buku di perpustakaan, merusak koleksi buku di perpustakaan, melakukan pengrusakan fasilitas perpustakaan dan fasilitas kampus pada umumnya.

4. Nilai Tanggung Jawab

Sebagai calon pemimpin di masa depan, pemustaka diharapkan memiliki nilai tanggung jawab yang tinggi terhadap status mereka sabagai pengguna perpustakaan. Bagaimana mereka bertanggung jawab terhadap tata tertib yang ada di perpustakaan STAIN Kudus, bisa memahami dan melaksanakan hak dan kewajiban mereka sesuai dengan aturan yang berlaku, melakukan apa yang boleh dilakukan serta menjauhi apa yang tidak boleh dilakukan. Selain itu, seorang pustakawan harus menekankan kepada pemustaka bagaimana kemauan mereka untuk bertanggung jawab merawat, menjaga dan tidak merusak atau menghilangkan buku koleksi perpustakaan yang dipinjam, juga bentuk tanggung jawab pemustaka untuk membayar sejumlah denda yang dibebankan jika pemustaka tersebut mengalami keterlambatan pengembalian koleksi buku perpustakaan.

Dalam kaitanya dengan penanaman pendidikan nilai pada kegiatan user education, maka pustakawan UPT Perpustakaan STAIN Kudus, dapat mengupayakan hal-hal seperti berikut ini dalam kegiatan user education : 
1. Melalui pendekatan emosional.

Tak kenal, maka tak sayang, begitulah sebuah pepatah mengatakan. Dalam kegiatan user education, interaksi antara pustakawan dan peserta (mahasiswa baru) haruslah tidak berjarak, formal namun tidak kaku. Melemparkan beberapa joke segar, dapat mencairkan suasana sehingga tidak terkesan membosankan dapat meningkatkan keakraban antara pustakawan dan peserta user education dan peserta juga semakin aware terhadap materi yang akan disampaikan. Dalam hal ini Pustakawan menempatkan diri sebagai seorang "kakak" yang dapat membimbing adik-adik mahasiswa untuk bagaimana menempatkan diri sebagai pemustaka/user yang baik dan santun. Dengan pendekatan emosional yang berhasil, maka interaksi pemustaka/user dengan pustakawan atau bahkan pengelola perpustakaan akan lebih erat dan bersahabat.

2. Melalui contoh teladan atau inspirasi

Setelah dapat mengakrabkan diri dengan peserta, pustakawan dapat berbagi cerita tentang pengalaman pribadi dirinya dalam melakukan pelayanan di perpustakan, bagaimana bertemu dan melayani dengan berbagai macam user/pemustaka yang berlainan karakter atau bahkan dapat saling berinteraksi misalnya memberikan kesempatan kepada peserta user education untuk menyampaikan pengalaman mereka dalam memanfaatkan jasa perpustakan selama bersekolah di SMA/SMK/MA. Dari saling sharing pengalaman tersebut akan ada pengalaman berharga yang kelak akan menjadi inpirasi bahkan teladan bagi peserta user education. Hal lain yang dapat dilakukan oleh pustakawan STAIN Kudus adalah dapat memotivasi mahasiswa baru untuk lebih meningkatkan budaya membaca, meningkatkan budaya berliterasi ilmiah karena mereka telah memasuki dunia pendidikan yang lebih baru dan lebih kompleks yaitu dunia pendidikan perguruan tinggi. 
3. Penanaman nilai dilakukan dari contoh yang sederhana Proses penanaman nilai harus dimulai dari hal-hal yang sangat sederhana, pustakawan dapat memberikan contoh sederhana misalnya mengembalikan buku tepat waktu, tidak mencorat-coret dan merusak buku koleksi perpustakaan, bahkan dalam hal sangat yang sangat sederhana seperti tidak berlama-lama menggunakan fasilitas komputer pencarian katalog di perpustakaan STAIN kudus yang jumlahnya sangat terbatas. Salah satu hal yang paling sering disampaikan oleh pustakawan STAIN Kudus kepada user education, adalah pentingnya untuk tidak merusak kerapian tatanan koleksi buku sehingga pemusataka/user yang lain tidak mengalami kesulitan dalam mencari buku yang akan mereka butuhkan.

4. Penanaman nilai dilakukan dengan secara repetitif/diulangulang

Proses penanaman nilai harus dilakukan secara berulangulang, semakin lama semakin tertanam, menjadi kebiasaan dan lama-lama menjadi bagian dari kepribadianya. Dalam hal ini, secara berulang-ulang pustakawan tidak boleh bosan untuk mengingatkan kepada user/pemustaka tentang bagaimana pentingnya mentaati peraturan tata tertib di perpustakaan, dan menyampaikan bahwa tata tertib dibuat untuk kepentingan dan kebaikan pemustaka sendiri.

\section{d. Kendala Dalam Pelaksanaan Kegiatan User Education Tahun Akademik 2017/2018}

Walaupun sudah berusaha $100 \%$ agar kegiatan user education di UPT perpustakaaan STAIN Kudus bisa terlaksana dengan baik, masih terdapat beberapa kendala yang menjadi penghambat kegiatan tersebut, antara lain :

1. Perbandingan jumlah pemateri dan peserta user education yang sangat jauh, dengan hanya 6 pemateri harus memandu 
2611 mahasiswa baru. Dalam praktek di lapangan, pada 1 kelompok, 1 pemateri memandu 100 mahasiswa lebih.

2. Pelaksanaan user education bersamaan dengan kegiatan kuliah, sehingga dikahawatirkan mengganggu kegiatan belajar mengajar mahasiswa yang akan mengikuti user education di perpustakaan STAIN Kudus.

3. Gedung perpustakaan STAIN Kudus yang kurang representatif, diakrenakan pada saat kegiatan user education, layanan perpustakaan juga tetap buka seperti biasa, maka gedung perpustakaan yang cukup kecil untuk menampung jumlah mahasiswa sebanyak itu terasa sesak dan pelayanan administrasi maupun sirkulasi di perpustakaan agak terganggu.

4. Kartu mahasiswa belum jadi, sehingga mahasiswa yang telah mengikuti user education kesulitan untuk segera menjadi anggota aktif perpustakaan.

\section{Simpulan}

Sebagai perpustakaan di sebuah institusi perguruan tinggi, UPT perpustakaan STAIN Kudus, selalu dituntut untuk dapat memberikan pelayanan terbaik bagi user/pemustaka, dalam hal ini adalah dosen, mahasiswa,dan tenaga kependidikan lainya. Selain itu perpustakaan selalu dituntut untuk bisa menyediakan sumber informasi berupa bahan pustaka yang lengkap, up to date dan sesuai dengan kebutuhan user/pemustaka.

Tuntutan user/pemustaka yang semakin tidak terbatas, terkadang tidak dibarengi dengan kemampuan mereka untuk secara benar, efektif dan efisien dalam memanfaatkan jasa pelayanan di perpustakan, bahkan terkesan hanya "yang penting kebutuhan saya terpenuhi"

Kegiatan User Education UPT perpustakaan STAIN Kudus sebagai salah satu bentuk layanan yang diberikan oleh UPT perpustakaan STAIN Kudus dianalogikan sebagai dua sisi mata 
uang, secara ideal dimaksudkan untuk membantu pemustaka dalam hal ini para mahasiswa baru di STAIN Kudus untuk dapat memanfaatkan layanan di perpustakaan STAIN Kudus secara efektif dan efisien.

Pada sisi yang lain, kegiatan user education juga diaplikasikan sebagai sebuah proses penanaman pendidikan nilai bagi pemustaka di STAIN Kudus. Pustakawan STAIN Kudus sebagai pemateri dalam kegiatan tersebut dituntut untuk dapat menyisipkan pendidikan nilai kepada pemustaka, hal tersebut dimaksudkan agar dapat membentuk karakter pemustaka yang tertib aturan, sopan, dan santun dalam memanfaatkan layanan di perpustakaan STAIN Kudus.

Pendidikan nilai sebagai unsur yang sangat penting dalam dunia pendidikan dimana dalam pendidikan tersebut diharapkan akan mengembangkan nilai-nilai pada diri user/pemustaka seperti nilai kebenaran,nilai keindahan, nilai kesopanan,nilai kejujuran,nilai kebaikan, dan nilai tanggung jawab

Pustakawan sebagai ujung tombak atau leader dalam kegiatan user education di perpustakaan STAIN Kudus diharapkan dapat menerapkan dirinya menjadi pendidik atau edukator yang dapat menjadikan dirinya teladan, contoh yang baik, menjadi motivator bakan dapat menjadi inspirator bagi pemustaka yang dibimbingnya dalam kegiatan user education tersebut. 


\section{DAFTAR PUSTAKA}

Abdul Hak,Ade. "Pendidikan pemakai: Perubahan perilaku pada siswa madrasah dalam sistem pembelajaran berbasis perpustakaan." AL-MAKTABAH 6, no. 1 (Oktober 2004).

Hermawan, Rahman, dan Zen,Zulfikar. Etika kepustakawanan. Yogyakarta: CV Sagung Seto, 2010.

Hidayat, Aat. "REKONSTRUKSI PERAN PUSTAKAWAN DI ERA GLOBALISASI." LIBRARIA: Jurnal Perpustakaan 4, no. 2 (2017): 467-480.

"Kamus Besar Bahasa Indonesia Versi Daring." Diakses 15 Mei 2018. www.kbbi.web.id.

Mawardi, Lubis. Evaluasi Pendidikan Nilai. Yogyakarta: Pustaka Pelajar, 2009.

Mulyana, Rohmat. Mengartikulasikan pendidikan nilai. Bandung: Alfabeta, 2004.

Pradhika, Grantino One. "Pengaruh Pendidikan Pengguna (User Education) Terhadap Pemanfaatan Layanan Perpustakaan Di UPT Perpustakaan Universitas Muhammadiyah Suakarta." Libri-Net 3, no. 2 (Juni 2014).

Qiqi Yulianti Zakiah, dan Rusdiana. Pendidikan Nilai: Kajian Teori dan Praktik di Sekolah. Bandung: Pustaka Setia, 2014.

Rangkuti, Lailan Azizah. "Pentingnya pendidikan pemakai (User education) di perpustakaan perguruan tinggi." Iqra' 8, no. 01 (Mei 2014).

Yuniarti, Yuyun. "Pendidikan Ke Arah Pembentukan Karakter." Tarbawiyah 11, no. 2 (Desember 2014). 
